\title{
Impact of glycemic control on advanced glycation and inflammation in overweight and obese patients with type 2 diabetes mellitus
}

\author{
Kalninova $\mathrm{J}^{1}$, Jakus $\mathrm{V}^{1}$, Glejtkova $\mathrm{M}^{2}$, Kuracka $\mathrm{L}^{1}$, Sandorova $\mathrm{E}^{1}$ \\ Institute of Medical Chemistry, Biochemistry and Clinical Biochemistry, Faculty of Medicine, Comenius University, \\ Bratislava, Slovakia. jana.kalninova@fmed.uniba.sk
}

\begin{abstract}
Aim: In this study we tried to investigate the impact of glycemic control on parameters of glycation and inflammation in overweight and obese patients with type 2 diabetes mellitus.

Patients and methods: Markers of glycation ( $\mathrm{HbA}_{1 \mathrm{c}}$, AGEs; measured by HPLC and spectrofluorimetry, resp.) and inflammatory markers (IL-6, IL-8, TNF- $\alpha$, MCP-1; measured by XMAP technology) were assessed in 69 patients with T2DM, of whom 32 were patients were with poor glycemic control (PGC group), 37 patients were with good glycemic control (GGC group) and 23 were healthy blood volunteers.

Results: Our results showed that plasma levels of fluorescent AGEs, IL-6, IL-8, TNF- $\alpha$, and MCP-1 were significantly increased in PGC and GGC groups in comparison with control group, while the levels were higher in PGC group in comparison with GGC group, but the difference was not significant. We found a positive correlation between AGEs and MCP-1 and between TNF- $\alpha$ and creatinine in PGC group. We found significantly decreased levels of glycated $\mathrm{HbA}_{1 \mathrm{c}}$ and $A G E s$ in patients who used statins compared to patients who used fibrates. We observed beneficial impact of treatment with oral antidiabetic (OAD) agents + insulin on levels of IL-8, TNF- $\alpha$ and TAG in comparison with treatment with insulin alone.

Conclusions: Despite good glycemic compensation of patients with T2DM, levels of AGEs and inflammatory markers remained significantly elevated in comparison with healthy controls. There was a beneficial impact of treatment with OAD agents + insulin in sense of lowering the low-grade inflammation (Tab. 3, Fig. 7, Ref. 113). Text in PDF www.elis.sk.

Key words: glycemic control, overweight, obesity, diabetes mellitus, inflammation,
\end{abstract}

\begin{abstract}
Abbrevations: AGEs - advanced glycation end products, ALB albumin, ALT - alanine aminotransferase, AST - aspartate aminotransferase, BIL - bilirubin, BMI - body mass index, CML - Ncarboxymethyllysine, CRP - C-reactive protein, CRT creatinine, DBP - diastolic blood pressure, DR - diabetic retinopathy, FBG - fasting blood glucose, FFA - free fatty acids, GGC - good glycemic compensated, GMT - gamma glutamyltransferase, $\mathrm{HbA}_{1 \mathrm{c}}$ - glycated hemoglobin, HDL-C - high density cholesterol, I - insulin, IL-1 $\beta$ - interleukin-1 beta, IL-6 - interleukin 6, IL-8 - interleukin 8, ICAM-1 - intercellular cell adhesion molecule-1, LDL-C - low density cholesterol, LMW - low molecular weight, MCP-1
\end{abstract}

${ }^{1}$ Institute of Medical Chemistry, Biochemistry and Clinical Biochemistry, Faculty of Medicine, Comenius University, Bratislava, Slovakia, and ${ }^{2}$ Institute of Medical Biochemistry, Jessenius Faculty of Medicine, Comenius University, Martin, Slovakia

Address for correspondence: J. Kalninova, Dr, Institute of Medical Chemistry, Biochemistry and Clinical Biochemistry, Faculty of Medicine, Comenius University, Spitalska 24, SK-813 72 Bratislava, Slovakia. Phone: +421.2.59357324, Fax: +421.2.59357415

Acknowledgements: This study was supported by grants VEGA 1-037509, VEGA 1-0451-12 and UK/187/2011. The authors thank Boris Krahulec Assoc. Prof., MD, PhD, Viliam Mojto, Assoc. Prof. MD, PhD, and Martin Čaprnda MD, PhD for assistance with subject recruitment as well as Michal Sapák, MD, PhD for technical assistance.
- monocyte chemoattractant protein-1, NADPH - nicotinamide adenine dinucleotide phosphate, NDR - no diabetic retinopathy, $\mathrm{NF} \kappa \mathrm{B}$ - nuclear factor kappa B, NPDR - non-proliferative diabetic retinopathy, $\mathrm{OAD}$ - oral antidiabetic, $\mathrm{PGC}$ - poor glycemic compensated, RAGE - receptor for AGE, ROS - reactive oxygen species, SBP - systolic blood pressure, SD - standard deviation, T2DM - type 2 diabetes mellitus, TAG - triacylglycerols, TC total cholesterol, TNF- $\alpha$ - tumor necrosis factor-alpha, VCAM-1 - vascular cell adhesion molecule-1, VEGF - vascular endothelial growth factor, $\mathrm{WC}$ - waist circumference.

Many chronic diseases are now in pandemic proportions and increasingly becoming the major cause of morbidity and mortality worldwide. Diabetes mellitus, especially type 2 diabetes mellitus (T2DM), plays a starring role in this problem, with diabetic complications being a very important public health issue (Beaglehole and Yach, 2003). Diabetes mellitus is a metabolic disorder which is characterized by hyperglycemia and glucose intolerance due to insulin deficiency, impaired effectiveness of insulin action, or both. Diabetes mellitus, especially T2DM, is a public health problem which has reached epidemic proportions due the rapidly increasing rates of this disease worldwide. Target organ complications secondary to diabetes will be one of the most important medical concerns in the coming decades (Navarro and Mora, 2005). 
Hyperglycemia is a common feature of diabetes mellitus, and the main pathogenic factor of diabetes and vascular (Hegab et al. 2012) andother complications (Miller et al., 1996; Korpáš and Jakuš, 2000). Hyperglycemia was shown to act deleteriously through a number of pathways, including the aldose reduction pathway, advanced glycation end product (AGE) pathway, reactive oxygen intermediate pathway, and PKC pathway (King, 2008). Hyperglycemia also induces both postprandial and chronic lowgrade inflammation (Calder et al, 2011). Long-term hyperglycemia is linked with glycation, glycoxidation, oxidative stress, and inflammation (Aronson, 2008; Negre-Salvayre et al, 2009). The degree of glycation of hemoglobin provides information about the glucose level (quality of diabetes control) over previous 6-8 weeks (Racz et al, 1989).

Advanced glycation end products (AGEs) are considered to be a heterogenous group of compounds that arise non-enzymatically by the reaction of reducing sugars and other $\alpha$-carbonylic compounds with amino groups, not only with proteins but also with lipids and nucleic acids. Schiff's base, which results from condensation of glucose with a lysine residue on a protein, typically undergoes a so-called Amadori rearrangement resulting in fructosamine (ketosamine) structure. This is the reason why one of the best known Amadori products, $\mathrm{HbA}_{1 \mathrm{c}}$, adduct of hemoglobin and glucose, can be used as a major indicator for hyperglycemia. Further rearrangements, oxidations and eliminations are needed to finally form the members of the highly heterogenous group of AGEs (Nass and Simm, 2009).

AGEs have a pathogenic importance in diabetes (Sebekova and Somoza, 2007). The formation of AGEs is an important biochemical abnormality that accompanies diabetes mellitus and likely also inflammation in general (Basta et al, 2003). AGEs induce cross-linking processes in the structure of long-lived proteins such as collagen. By binding to their specific receptor, they activate intracellular signaling pathways which lead to cytokine production, responsible for proinflammatory and prosclerotic effects (Inagaki et al, 2003).

AGEs detectable in vivo include three main groups: (1) Fluorescent cross-linking AGEs such as pentosidine and crossline; (2) Non-fluorescent cross-linking AGEs such as imidazolium dilysine cross-links named either glyoxal lysine dimer or methylglyoxal lysine dimer result from reactions taking place between glyoxal derivates and lysine residues; (3) Non-cross-linking AGEs such as N-carboxymethyllysine (CML) (Hegab et al, 2012). The formation of AGEs is supressed by intensive glycemic control and may be suppressed in future by thiamine and pyridoxamine supplementation and several other pharmacological agents. However, when complications are already present, the improvement in glycemic control alone does not have to be sufficient to prevent the continued progression of these pathological processes, potentially due to irreversibility of AGEs deposits formation, and poor clearance mechanisms (Hatfield, 2005).

AGEs interact with certain receptors such as that for AGE (RAGE) to induce intracellular signalling that leads to enhanced oxidative stress and elaboration of key proinflammatory and prosclerotic cytokines (Goh and Cooper, 2008). AGE receptor RAGE is a multiligand member of the immunoglobulin superfamily of cell surface molecules. AGE-receptor interaction can alter the functions of macrophages, and endothelial, mesangial and mesothelial cells, and can induce inflammation. Oxidative stress, vascular permeability, vascular cell adhesion molecule-1 (VCAM-1) overexpression, and monocyte chemoattractant protein-1 (MCP1) production have been observed after cell activation by AGEs. AGEs appear to be involved in the genesis of diabetic macro- but also microangiopathy such as retinopathy and glomerulosclerosis (Boulanger et al, 2006). The AGE/RAGE interaction activates a series of intracellular signalling pathways, including nicotinamide adenine dinucleotide phosphate (NADPH) oxidase and nuclear factor kappa-B $(\mathrm{NF} \kappa \mathrm{B})$, with production of reactive oxygen species (ROS) (Wautier et al, 2001). The cellular response can involve several types of processes - proinflammatory, profibrotic, procoagulant and/or angiogenic - with overexpression of cell adhesion molecules such as vascular cell adhesion molecule-1 (VCAM-1), and production of cytokines such as interleukin-6 (IL-6) and tumor necrosis factor- $\alpha(\mathrm{TNF}-\alpha)$, tissue factor and vascular endothelial growth factor (VEGF) (Schmidt et al, 2001; Boulanger et al, 2002; Wautier and Schmidt, 2004; Boulanger et al, 2007).

Activation of inflammatory processes may contribute to the development of T2DM. In addition, inflammation appears to be a major mechanism responsible for vascular damage leading to the clinically well-recognized complications of diabetes. Activation of growth factors and adhesion molecules may promote the movement of inflammatory cells into the renal microvasculature, thus predisposing to the development of diabetic nephropathy. Emerging evidence also indicates that markers of inflammation are associated with the more severe forms of diabetic retinopathy (Williams and Nadler, 2007). Inflammation is considered to be a key regulator of the pathogenesis of T2DM, but what triggers this inflammation is still unknown (Pickup and Crook, 1998). However, it may be related to obesity. Obesity is associated with enlargement of adipose tissue, and consequently increases the number of adipose tissue macrophages (Cinti et al, 2005; Goyal et al, 2012). These macrophages are responsible for almost all adipose tissue TNF- $\alpha$ expression, significant amounts of IL-6, and other acute-phase response markers and mediators of inflammation (Weisberg et al, 2003; Cinti et al, 2005; Popko et al, 2010). Low-grade inflammation is a characteristic feature of obese state. Obese people have higher circulating concentrations of many inflammatory markers than lean people do, and these are believed to play a role in causing insulin resistance and other metabolic disturbances (Calder et al, 2011). Obesity is associated with an increased risk of developing T2DM, fatty liver disease, hypertension and vascular complications (Williams and Nadler, 2007). Proinflammatory and antiinflammatory bioactive molecules produced from adipose tissues contribute to the burden of obesity-related diseases (Donath and Shoelson, 2011). Adipose tissue consists of heterogeneous populations of adipocytes, stromal preadipocytes, immune cells, and vascular cells, and it can respond rapidly and dynamically to alterations in nutrient excess caused by enhanced food consumption through adipocyte hypertrophy and hyperplasia (Shoelson et al, 2006). This results in a local inflammation in adipose tissue that 
propagates an overall systemic but chronic low-grade inflammation associated with the development of obesity-related comorbidities such as type 2 diabetes and cardiovascular diseases (Yamamoto and Yamamoto, 2013). The possibility that obesity, and the activation of adipose tissue in particular, may enhance the release of inflammatory factors that underlie the development of insulin resistance has generated intense interest in the field of diabetes for a number of reasons.

The TNF-family of cytokines plays an important role in regulating inflammation and apoptosis. The first cytokine discovered is TNF- $\alpha$, which is produced by neutrophils, macrophages, and adipocytes and can induce other powerful cytokines such as IL-6, which in turn regulates the expression of C-reactive protein (CRP). CRP increases the expression of endothelial ICAM-1, VCAM-1, E-selectin and MCP-1 (Pasceri at al, 2000; Venugopal et al, 2002). The proinflammatory cytokines IL- $1 \beta$, IL- 6 , and TNF- $\alpha$ have cytotoxic, cytostatic (inhibition of insulin synthesis and secretion), or cytocidal actions to pancreatic islets by inducing nitric oxide production (Rapoport et al, 1998; Erbagci et al, 2001; Tchorzewski et al, 2001). Chemokines have a role in inflammation (Buc and Bucova, 2000). Elevated plasma free fatty acids (FFA), leptin, resistin, TNF- $\alpha$ and IL- 6 concentrations have been reported in obese subjects (Bastard et al, 2006; Hajer et al, 2008; Rasouli and Kern, 2008). Previous studies suggested that low-grade systemic inflammation plays a role in pathogenesis of some glucose disorders in adults (prediabetic state) (Pickup and Crook, 1998). Several crosssectional studies showed that insulin resistance and type 2 diabetes are associated with higher levels of C-reactive protein (CRP), IL-6, and TNF- $\alpha$ (Nilsson et al, 1998; Yudkin et al, 1999; Ford, 1999; Festa et al, 2000; Frohlich et al, 2000; Temelkova-Kurktschiev et al, 2002). Furthermore, various longitudinal studies have shown that elevated levels of IL-6 predict the development of T2DM (Pradhan et al, 2001; Freeman et al, 2002; Festa et al, 2002).

The aim of our study was to evaluate the impact of glycemic control on glycation $\left(\mathrm{HbA}_{1 \mathrm{c}}\right.$, AGEs) and inflammation (IL-6, IL8 , TNF- $\alpha$, MCP-1) in overweight and obese patients with T2DM.

\section{Patients and methods}

\section{Study patients and design}

The study was approved by our local ethics commitee and every subject accepted to participate by signing a written informed consent.

Plasma was obtained after 12 hours of overnight fasting from 23 healthy control subjects and 69 overweight and obese patients with T2DM. Plasma was obtained from 2nd Internal Medicine Clinic, University Hospital, Mickiewiczova, Bratislava. Plasma was stored frozen at $-70{ }^{\circ} \mathrm{C}$.

Exclusion criteria were pregnancy or lactation, cancer, mental health problems, and secondary diabetes. All T2DM patients were divided into 2 groups according to the value of glycated hemoglobin $\left(\mathrm{HbA}_{1 \mathrm{c}}\right)$. The patients with $\mathrm{HbA}_{1 \mathrm{c}} \leq 6 \%$ had good glycemic control (GGC group, $\mathrm{n}=37$ ) and those with $\mathrm{HbA}_{1 \mathrm{c}}>6 \%$ had poor glycemic control (PGC group, $\mathrm{n}=32$ ) regardless of presence of diabetic complications.
Sixteen patients used oral antidiabetic (OAD) agents, 7 patients used OAD agents and had diet, 5 patients were treated with a combination of insulin and $\mathrm{OAD}$ agents $(\mathrm{I}+\mathrm{OAD})$, and 6 patients were treated with insulin alone. Twenty patients received lipid or cholesterol lowering drugs (16 statins, 4 fibrates). Forty-four patients were without diabetic complications (NC), 13 patients had microvascular complications (micro VC) and 8 patients had in addition to micro VC also macrovascular complications (micro+macro VC).

\section{Clinical and anthropometric assessment}

Resting blood pressure levels were measured in the left arm in a sitting position by sphygmomanometer (Omron M3, Intellisense, Japan). Body weight and height were measured without shoes and with light clothing using a digital weighing and measuring station with automatic body mass index (BMI) calculation $\left(\mathrm{kg} / \mathrm{m}^{2}\right.$, SECA 764 , Germany). Overweight was defined by BMI $>25 \leq 30$ and obesity by BMI $>30$. Waist circumferences were measured in centimeters with an inelastic tape to the nearest millimeter with the subject in a standing position.

\section{Determination of basic biochemical parameters}

Fasting blood glucose (FBG) was measured by glucose oxidase method using Hitachi 911 Analyser (Roche Diagnostic, Switzerland).

Serum total cholesterol (TC), high density cholesterol (HDLC), low density cholesterol (LDL-C) and triacylglycerols (TAG) were evaluated enzymatically and colorimetrically using automatic analyser Cobas Integra 400 (Roche, Switzerland). Serum creatinine was estimated using enzymatic method (Vitros 250, Johnson and Johnson Company, USA).

Analyses of creatinine (CRT), aspartate aminotransferase (AST), alanine aminotransferase (ALT), gamma glutamyltransferase (GMT), albumin (ALB) and bilirubin (BIL) were assessed by standard methods as part of routine examination of patients at 2nd Internal Medicine Clinic, University Hospital, Mickiewiczova, Bratislava, Slovakia.

\section{Determination of $\mathrm{HbA}_{1 c}$ and advanced glycation}

HbA1c was measured by HPLC (DiaSTAT, Bio-RAD, USA) using the IFCC calibration. Determination of AGEs (i.e. some fluorescent products from the family of AGEs) was based on the spectrofluorimetric detection according to Henle et al (1999) and Münch et al (1997) in modification by Kalousová et al (2001). Blood plasma was diluted 1:50 with PBS pH 7.4 and fluorescence intensity was recorded at the emission maximum at $445 \mathrm{~nm}$ upon excitation at $370 \mathrm{~nm}$ (spectrofluorimeter Perkin Elmer LS 45). Fluorescence intensity was expressed in arbitrary units (AU)/g protein.

\section{Determination of inflammatory markers}

Plasma levels of IL-6, IL-8, TNF- $\alpha$ and MCP-1 were determined using Fluorokine MAP cytokine multiplex kit designed for use with Athena Multi-Lyte Luminex ${ }^{\circledR} 100^{\mathrm{TM}}$ analyser produced at R\&D Systems (Minneapolis, MN, USA) according to the manufacturer's instructions. The cytokines were analysed using xMAPтM technology which combines the principle of sandwich 
immunoassay with fluorescent-bead-based technology allowing multiplex analysis of up to 100 different analytes in a single microtiter well.

\section{Statistical analysis}

For statistical analysis we used softwares Origin 8 and Excel 2010. Normality of data distribution was found out using Shapiro-Wilk test. Extremely different data were excluded from further calculations. When all groups of data of given parameter were Gauss' distributed, we compared them using ANOVA 1 factor without repetition and Bonferroni post-hoc test for evaluation of significant differences between pairs. For graphical expression we used column diagrams and values were expressed as means \pm standard deviation (SD). If one of compared data files did not demonstrate normal distribution, we used Kruskal-Wallis test and the next Bonferroni test. In case of two data files we used MannWhitney nonparametric test. Graphical expression was carried out using Box-plot diagrams, and results were expressed as median (1st, 3rd quartile). The correlation between the measured parameters was examined using the Pearson's correlation test or by the Sperman's rank correlation test $(r, p)$. P value less than 0.05 was considered statistically significant.

\section{Results}

\section{Comparison of baseline and biochemical parameters \\ Baseline characteristics of subjects}

Baseline characteristics of subjects are shown in Table 1. We observed significantly higher waist circumference (WC) and systolic blood pressure (SBP) in PGC and GGC group in comparison

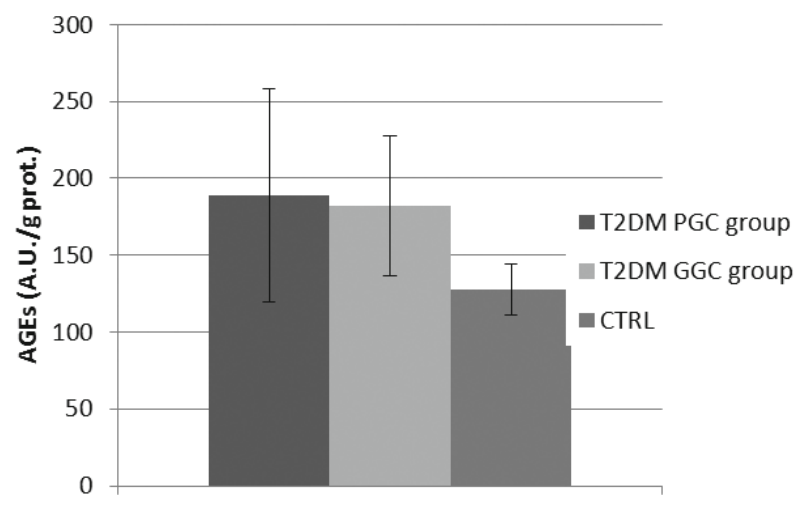

Fig. 1. Levels of AGEs in PGC, GGC and control groups.

with control group. There were no differences in body mass index (BMI) and diastolic blood pressure (DBP) in PGC and GGC groups in comparison with control group.

\section{Biochemical parameters of subjects}

Biochemical parameters of subjects are shown in Table 2. Biochemical evaluation revealed a significantly higher fasting glucose (FBG) and TAG in PGC and GGC group in comparison with control group. HDL-C was significantly lower in PGC and GGC group in comparison with control group.

Parameters of advanced glycation and inflammation of subjects

Parameters of advanced glycation and inflammation are shown in Table 3. We found significantly increased plasma levels of AGEs (Fig. 1), TNF- $\alpha$ (Fig. 2), IL-6 (Fig. 3), IL-8 (Fig. 4), and MCP-1

Tab. 1. Baseline characteristics of subjects.

\begin{tabular}{|c|c|c|c|}
\hline Parameter & PGC group & GGC group & CTRL group \\
\hline Age (years) & $63.00(58.50-68.50) *$ & $62.00(57.00-70.00)^{*}$ & $49.00(40.50-58.00)$ \\
\hline DD (years) & $14.00 \pm 8.10$ & $11.00 \pm 7.70$ & - \\
\hline BMI $\left(\mathrm{kg} / \mathrm{m}^{2}\right)$ & $28.9(27.3-31.3)$ & $28.2(27.2-32.2)$ & $25(22.70-32.40)$ \\
\hline $\mathrm{WC}(\mathrm{cm})$ & $102(96-109) *$ & $102(97-108) *$ & $90(83.00-100.00)$ \\
\hline SBP (mmHg) & $148(130-158) *$ & $142(131-156) *$ & $120(120.00-130.00)$ \\
\hline $\mathrm{DBP}(\mathrm{mmHg})$ & $81(74-85)$ & $78(73-83)$ & $80(80.00-80.00)$ \\
\hline
\end{tabular}

Data are presented as means \pm standard deviation in data with normal distribution and as median (1st quartile -3 rd quartile) in data with non-normal distribution, * Significant difference in comparison with control group

Tab. 2. Biochemical parameters of subjects.

\begin{tabular}{|c|c|c|c|}
\hline Parameter & PGC group & GGC group & CTRL group \\
\hline FBG (mmol/l) & $9.90 \pm 2.90^{*}$ & $8.10 \pm 2.70^{*}$ & $5.20 \pm 0.40$ \\
\hline HbAlc $(\%)$ & $7.43 \pm 0.82^{*+}$ & $5.02 \pm 0.71 *$ & $5.16 \pm 0.42$ \\
\hline TC (mmol/1) & $5.16 \pm 1.10$ & $4.55 \pm 0.90$ & $4.97 \pm 1.20$ \\
\hline $\mathrm{TAG}(\mathrm{mmol} / \mathrm{l})$ & $1.57(1.2-2.2) *$ & $1.4(0.98-2.33) *$ & $1.22(0.96-1.75)$ \\
\hline HDL-C (mmol/l) & $1.25 \pm 0.30 *$ & $1.21 \pm 0.30 *$ & $1.44 \pm 0.30$ \\
\hline LDL-C (mmol/1) & $2.90 \pm 0.80$ & $2.49 \pm 0.70$ & $2.84 \pm 1.00$ \\
\hline $\operatorname{ALT}(\mu \mathrm{kat} / \mathrm{l})$ & $0.67(0.42-0.99)$ & $0.46(0.37-0.59)$ & $0.51(0.32-0.79)$ \\
\hline GMT $(\mu \mathrm{kat} / \mathrm{l})$ & $0.60(0.30-1.15)$ & $0.44(0.31-0.67)$ & $0.52(0.36-0.84)$ \\
\hline $\mathrm{BIL}(\mu \mathrm{mol} / 1)$ & $8.50(5.60-15.10)$ & $6.8(5.70-9.15)$ & $8.00(6.4-11.70)$ \\
\hline $\operatorname{ALB}(g / 1)$ & $45.00 \pm 2.60$ & $44.00 \pm 1.60$ & $44.00 \pm 5.10$ \\
\hline CRT $(\mu \mathrm{mol} / \mathrm{l})$ & $77.00 \pm 15.40$ & $76.00 \pm 18.00$ & $72.00 \pm 18.90$ \\
\hline
\end{tabular}

cant difference in comparison with control group, + significant difference between PGC and GGC group 
Tab. 3. Parameters of advanced glycation and inflammation of subjects.

\begin{tabular}{|c|c|c|c|}
\hline Parameter & PGC group & GGC group & CTRL group \\
\hline AGEs (AU/g proteins) & $189.00 \pm 69.40^{*}$ & $182.00 \pm 45.30 *$ & $128.00 \pm 16.50$ \\
\hline IL-6 $(\mathrm{pg} / \mathrm{ml})$ & $1.83(1.10-2.31) *$ & $1.94(1.24-2.68) *$ & $0.52(0.52-1.10)$ \\
\hline IL-8 (pg/ml) & $4.44(2.60-5.40) *$ & $3.96(2.72-5.08) *$ & $1.96(1.38-3.18)$ \\
\hline $\mathrm{TNF}-\alpha(\mathrm{pg} / \mathrm{ml})$ & $4.74(4.08-5.50) *$ & $4.52(4.08-4.96) *$ & $2.31(2.10-2.99)$ \\
\hline MCP-1 (pg/ml) & $101.2(24.81-148.00) *$ & $102.8(80.8-126.4) *$ & $14.72(10.54-22.04)$ \\
\hline
\end{tabular}

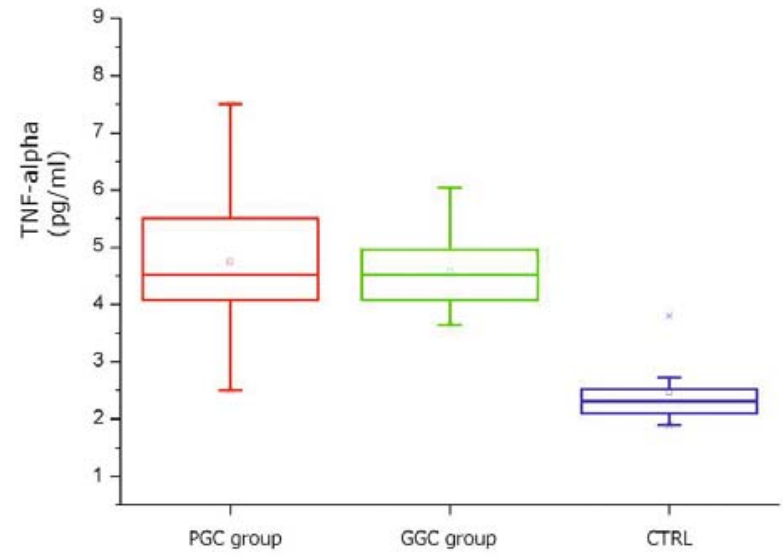

Fig. 2. Levels of TNF- $\alpha$ in PGC, GGC and control groups.

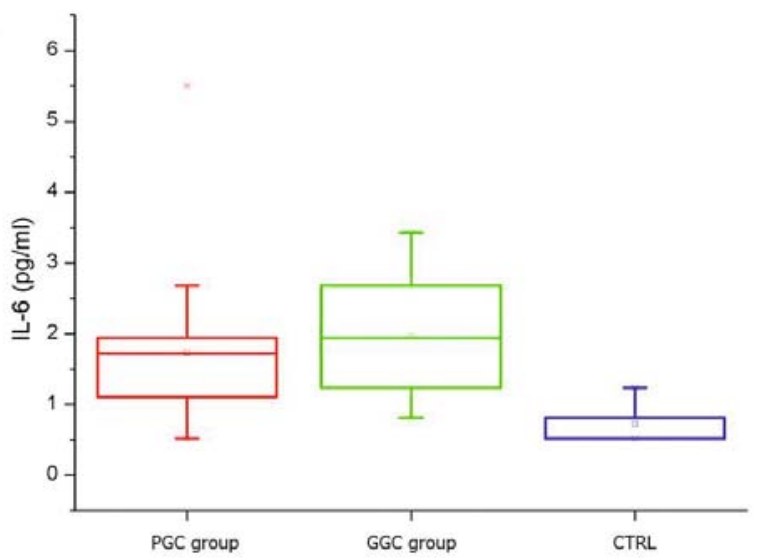

Fig. 3. Levels of IL-6 in PGC, GGC and control groups.

(Fig. 5) in both PGC and GGC groups in comparison with control group. We have found a difference between PGC and GGC groups, however it was not significant.

\section{Correlations between measured parameters}

Correlations of markers of advanced glycation and inflammation of subjects with baseline parameters

In PGC and GGC groups we did not find any correlations of measured parameters. In control group we found a significantly positive correlation of AGEs with age $(r=0.424, p=0.031)$. There was found a significantly negative correlation of IL- 6 and IL- 8 with $\operatorname{DBP}(\mathrm{r}=-0.470, \mathrm{p}=0.027$, respectively; $\mathrm{r}=-0.707, \mathrm{p}<0.0001)$.

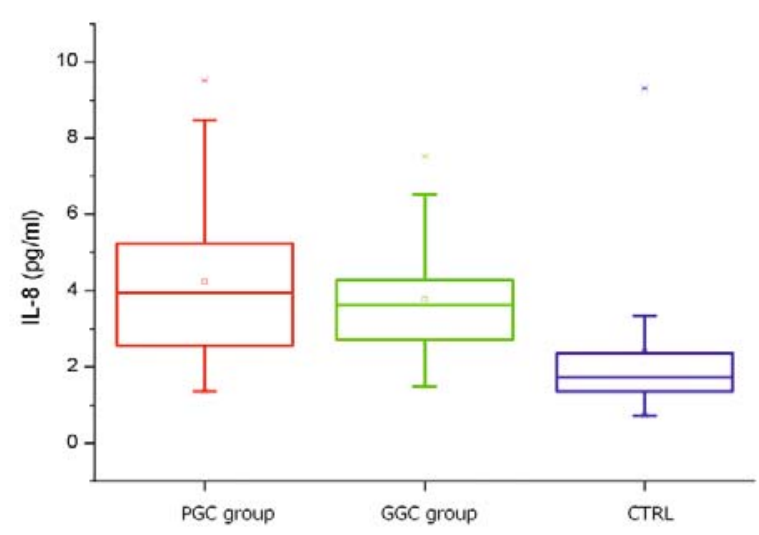

Fig. 4. Levels of IL-8 in PGC, GGC and control groups.

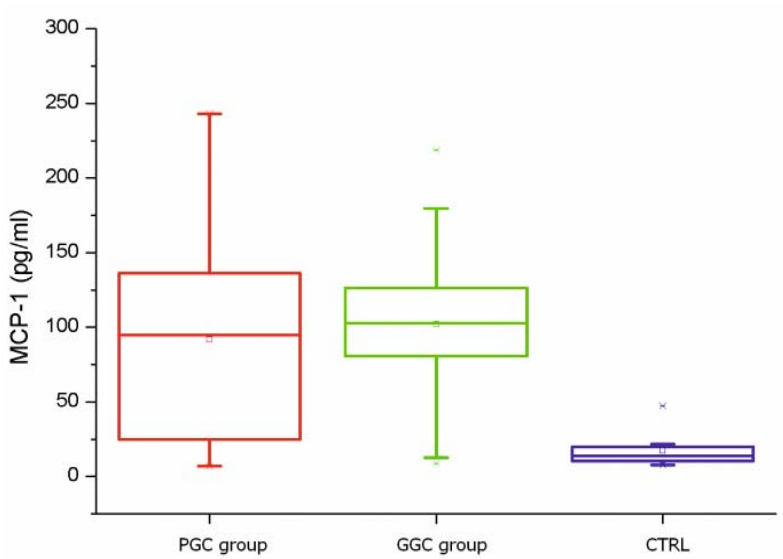

Fig. 5. Levels of MCP-1 in PGC, GGC and control groups.

There was found also a significantly negative correlation between TNF- $\alpha$ and age $(r=-0.461, p=0.020)$.

Correlations of markers of advanced glycation and inflammation of subjects with biochemical parameters

In PGC group we found a significantly positive correlation between AGEs and HDL $(r=0.511, p=0.011)$, significantly positive correlation between AGEs and MCP-1 $(r=0.659, p<0.0001)$ (Fig. 6), and significantly negative correlation between AGEs and TNF- $\alpha(r=-0.468, p=0.018)$. IL-6 was significantly positively correlated with creatinine $(r=0.625, p=0.002)$ (Fig. 7). There was a significantly negative correlation between IL-8 and albu$\min (r=-0.793, p=0.033)$ and significantly positive correlation 


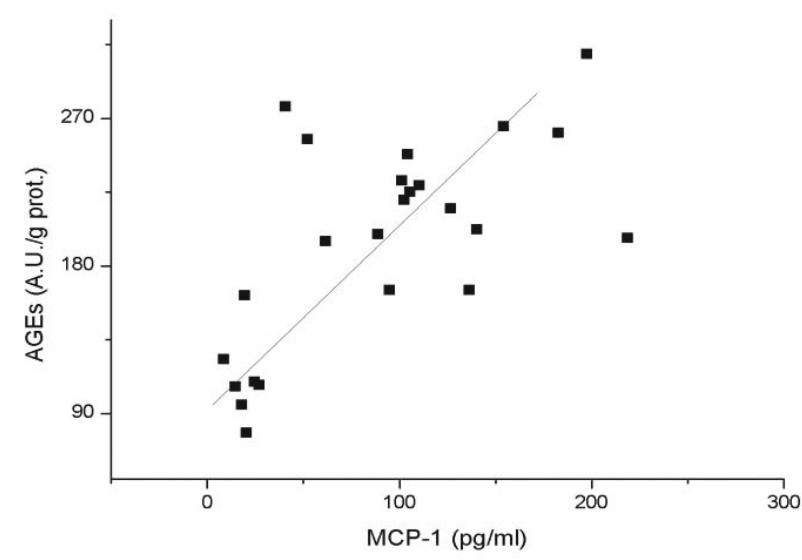

Fig. 6. Correlation between AGEs and MCP-1 in PGC group ( $r=$ $0.659, \mathrm{p}<0.0001)$.

between IL-8 and MCP-1 $(r=0.624, p=0.0001)$. We found a significantly negative correlation between TNF- $\alpha$ and MCP-1 (r $=-0.499, \mathrm{p}=0.007)$.

In control group we found a significantly negative correlation between AGEs and IL-6 $(r=-0.470, p=0.004)$. We found a significantly negative correlation between IL- 6 and TC $(r=-0.479, p$ $=0.015)$ and $\operatorname{LDL}(\mathrm{r}=-0.579, \mathrm{p}=0.007)$. We found a significantly positive correlation between IL-6 and IL-8 $(r=0.630, p=0.002)$. Next we found a significantly positive correlation between IL-8 and TNF- $\alpha(r=0.751, p<0.0001)$ and between IL-8 and MCP-1 $(\mathrm{r}=0.584, \mathrm{p}=0.004)$. There was found a significantly negative correlation between IL- 8 and LDL $(r=-0.489, p=0.046)$ and a significantly positive correlation between IL- 8 and TNF- $\alpha(\mathrm{r}=$ $0.744, \mathrm{p}<0.0001)$. Besides that, TNF- $\alpha$ was significantly negatively correlated with $\operatorname{LDL}(\mathrm{r}=-0.510, \mathrm{p}=0.031)$ and significantly positively correlated with MCP-1 $(r=0.629, \mathrm{p}=0.002)$.

\section{Effect of treatment}

We observed the effect of treatment in patients who used OAD agents $(n=16)$, OAD agents and had diet $(n=7)$, as well as in patients who were treated with a combination of insulin and OAD agents $(n=5)$ and patients who were treated with insulin alone $(\mathrm{n}=6)$.

The patients who were treated by insulin had significantly increased levels of IL- 8 compared to patients treated with OAD agents $7.52(5.40-7.84) \mathrm{pg} / \mathrm{ml}$ vs $3.96(3.04-4.92) \mathrm{pg} / \mathrm{ml}(\mathrm{p}=$ $0.004)$. We observed increased levels of IL- 8 in patients who were treated by insulin compared to patients treated with OAD agents + insulin $7.52(5.40-7.84) \mathrm{pg} / \mathrm{ml}$ vs 3.96 (3.04-5.24) pg/ $\mathrm{ml}(\mathrm{p}=0.018)$. Patients who used OAD agents + insulin had the same significantly decreased levels of TNF- $\alpha$ compared to patients who were treated with insulin $4.52(4.08-4.96) \mathrm{pg} / \mathrm{ml}$ vs 5.60 (5.50-5.84) pg/ml, ( $\mathrm{p}=0.004$, resp. 0.026). Patients who used OAD agents + had diet had significantly decreased levels of TNF- $\alpha$ compared to patients who were treated with insulin 4.08 $(4.08-4.52) \mathrm{pg} / \mathrm{ml}$ vs $5.60(5.50-5.84) \mathrm{pg} / \mathrm{ml}(\mathrm{p}=0.009)$. Patients

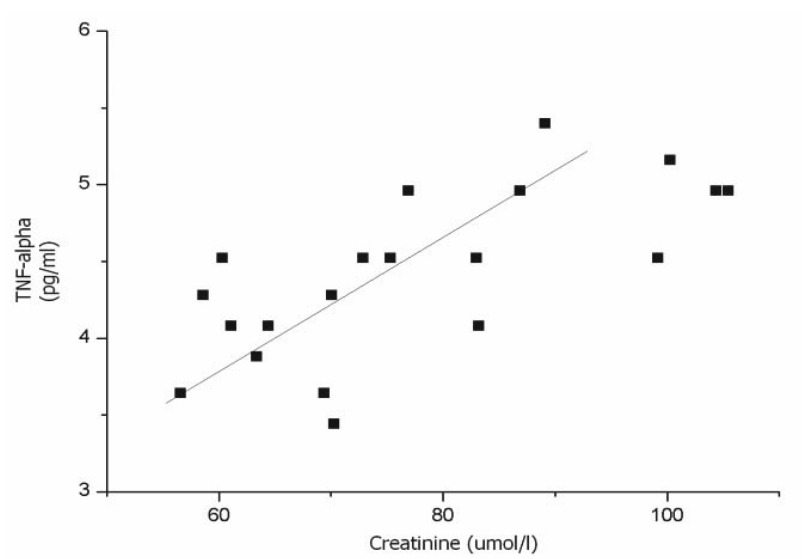

Fig. 7. Correlation between TNF- $\alpha$ and creatinine in PGC group ( $r$ $=0.720, p<0.0001)$.

who used OAD agents had significantly decreased levels of TAG compared to patients who were treated with OAD agents + insulin $2.10(1.32-2.55) \mathrm{mmol} / \mathrm{l}$ vs $1.22(0.98-1.47) \mathrm{mmol} / \mathrm{l}(\mathrm{p}=0.002)$. Our results showed that patients who used OAD agents had significantly decreased levels of AST compared to patients treated by OAD agents + insulin $0.53(0.44-0.60) \mu \mathrm{kat} / \mathrm{l}$ vs $1.22(0.98-1.47)$ $\mu \mathrm{kat} / \mathrm{l}(\mathrm{p}=0.045)$ and compared to patients treated by OAD agents + diet $0.53(0.44-0.60) \mu \mathrm{kat} / \mathrm{l}$ vs $0.33(0.32-0.36) \mu \mathrm{kat} / \mathrm{l}$ $(\mathrm{p}=0.030)$. TAGs were significantly decreased in patients who used OAD agents compared with patients who were treated with OAD agents + insulin $2.10(1.32-2.55) \mathrm{mmol} / 1$ vs 1.22 (0.98-1.47) $\mathrm{mmol} / \mathrm{l}(\mathrm{p}=0.002)$. Twenty patients had received lipid or cholesterol lowering drugs (16 statins, 4 fibrates). We found significantly decreased levels of $\mathrm{HbA}_{1 \mathrm{c}}$ in patients who used statins compared to patients who used fibrates ( $p=0.015$ ). We found significantly decreased levels of AGEs in patients who used statins compared to patients who used fibrates $(\mathrm{p}=0.050)$.

\section{Discussion}

The preclinical and clinical studies of the past years demonstrated a close participation of AGEs in all of the micro- and macrovascular complications of diabetes, especially in T2DM (Chilelli et al, 2013).

In our study, we found significantly elevated plasma levels of AGEs in poor and good glycemic compensation groups of overweight and obese patients in comparison with healthy control group.

Our findings are consistent with those of Kalousová et al (2002), who also found elevated levels of AGEs in T2DM. Dolhofer-Bliesener et al (1995) have described a small but significant increase in AGEs in diabetic patients. Ono et al (1998), Aso et al (2000), Zilin et al (2001), Kalousová et al (2002), Abou-Seif and Youssef (2004), Bush et al (2007), Piarulli et al (2009) also found significantly increased AGEs in plasma in all DM2 patients compared to control group.

In contrast to our findings there is the study of Wagner et al (2001) who demonstrated normal levels of fluorescent AGEs also 
in patients with $\mathrm{T} 2 \mathrm{DM}$ who had normal renal function. In patients with T2DM the concentration of AGEs seems to be mainly influenced by the quality of diabetes control (Hatfield, 2005). Intensive glycemic control in patients from DCCT trial led to a lower risk of diabetic microvascular complications compared to conventional treatment. The lower risk was associated with lower AGE levels, even after adjustment for $\mathrm{HbA}_{1 \mathrm{c}}$ (DCCT, 1993). The importance of glycemic control was also confirmed by our results. We believe that good glycemic control is an important part of prevention of developing pathological processes due to the irreversibility of AGE formation, and poor clearance mechanisms.

In their study, Gottsäter et al (2004) evaluated s-AGEs in T2DM patients at baseline and at follow up three years later. They revealed significantly increased levels of AGEs. They revealed that AGEs correlated significantly with plasma cholesterol, both at baseline and at follow up, plasma HDL cholesterol at baseline and with plasma LDL cholesterol at follow up. In addition, plasma LDL cholesterol at baseline correlated with AGEs at follow up. However, there were no significant correlations between $\mathrm{HbAlc}$ and AGEs.

Significantly higher AGE levels in diabetics compared to nondiabetics on regular hemodialysis treatment both before and after dialysis session were revealed Kalousová et al (2003). In this study AGEs did not correlate with parameters of glucose metabolism correction (FBG, $\mathrm{HbA}_{1 \mathrm{c}}$ ).

In the study of Makita et al (1991), the mean AGE content of samples of diabetic patients was significantly higher than that of samples from nondiabetic patients. Gul et al (2009) have found serum AGEs level significantly lower in control group in contrast to senile diabetic patients. Serum low-molecular weight AGEs were significantly higher in diabetics compared to non-diabetic subjects in the study of Sharp et al (2003). The serum levels of AGEs were higher in diabetic subjects without complications compared with nondiabetic subjects, higher among diabetic subjects with retinopathy and highest in diabetic subjects with both retinopathy and nephropathy in the study of Sampathkumar et al (2005). Sampathkumar et al (2005) found a significantly positive correlation between AGEs and glycated hemoglobin, cholesterol and triacylglycerols.

Mirza et al (2012) estimated that fluorescent AGEs correlated inversely with the magnitude of each complication. For instance, serum AGEs were significantly lower in patients without retinopathy versus mild, moderate or severe retinopathy and lower, but not significantly, in patients without peripheral neuropathy versus mild, moderate or severe peripheral neuropathy. In the study of Sharp et al (2003) there was no correlation between serum LMWAGEs and $\mathrm{HbAlc}$.

In contrast, Shimoike et al (2000) estimated that serum AGE levels in diabetic patients were not significantly higher than those in normal subjects.

In our study, we found out that plasma levels of proinflammatory markers IL-6, IL-8, TNF- $\alpha$ and MCP-1 were elevated in PGC and GGC overweight and obese patients. In agreement with our findings Barbarroja et al (2012) found increased TNF- $\alpha$ and IL-6 in obese people with type 2 diabetes. Czyzewska et al (2012) in their study divided the patients into three groups: group I - patients with type 2 diabetes with $\mathrm{HbA}_{1 \mathrm{c}} \geq 6.1-\leq 6.5 \%$, group II - patients with type 2 diabetes with $\mathrm{HbA}_{1 \mathrm{c}}>6.5-\leq 10.0 \%, \mathrm{~K}-$ control group. The average concentration of IL- 6 was highest in group I, lower in group II, and lowest in control group. Several cross-sectional studies showed that type 2 diabetes is associated with higher levels of TNF- $\alpha$ and IL-6 (Nilsson et al, 1998; Yudkin et al, 1999; Festa et al, 2000; Temelkova-Kurktschiev et al, 2002). Marques-Vidal et al (2013) in their study found that participants with diabetes had higher IL- 6 and TNF- $\alpha$ levels than participants without diabetes. According to Tönjes et al (2010), fasting serum TNF- $\alpha$ and fasting serum IL-6 levels were not significantly different among the groups in any of the prediabetic group compared to controls.

In contrast, Festa et al (2002) showed decreased levels of TNF- $\alpha$ and IL- 6 in T2DM compared to healthy controls. Decreased levels of inflammatory cytokines in their study were in disagreement with next findings. A recent study by Marques-Vidal et al (2013) found that subjets with T2DM had increased levels of IL-6 and TNF- $\alpha$. It was also reported, that high levels of inflammatory cytokines appear in early stages of type 2 diabetes mellitus and are capable of predicting the development of T2DM (Festa et al, 2002). In contrast to some of existing evidence, few studies found that no significant difference is seen in plasma TNF- $\alpha$ or IL-6 levels between obese and non-obese subjects (Tsigos et al, 1999).

Agarwal et al (2011) found that TNF- $\alpha$ levels in obese patients were higher than those in non-obese patients. However, the levels of IL- 6 were higher in non-obese group. Ahmad et al (2012) found levels of TNF- $\alpha$ and IL-6 highly elevated in obese subjects compared to lean subjects. It has been demonstrated by many researches that serum levels of TNF-alpha are elevated in obesity (Zahorska-Markiewicz et al, 2000; Laimer et al, 2002). TNF-alpha is involved in the pathophysiology of obesity-associated insulin resistance and atherosclerosis (Nieto-Vasquez et al, 2008; Yudkin, 2007). Tsigos et al (1999) showed that there is no significant difference in plasma TNF- $\alpha$ levels between obese and non-obese subjects.

Plasma levels of TNF- $\alpha$ and IL- 6 were moderately correlated in study of Rekeneire et al (2006). The correlation between TNF- $\alpha$ and IL- 6 was $0.19(p<0.0001)$. Levels of TNF- $\alpha$ and IL- 6 were siginficantly higher in diabetic group compared with the non-diabetic group. The association between diabetes and high level of inflammation remained even after adjustments for possible confounders such as demographics, lifestyle habits, total body fat, visceral fat, and comorbidities.

In agreement with our findings, the study of Chen et al (2003) found no correlation between fasting blood glucose and TNF- $\alpha$ and IL-6 levels in patients with T2DM.

We found a positive correlation between TNF- $\alpha$ and creatinine in PGC group. In agreement with our findings, TNF- $\alpha$ was positively correlated with creatinine $(\mathrm{p}<0.001)$ in the study of Zietz et al (2000). Kafle et al (2012) found correlation between creatinine and TNF- $\alpha$ and IL-6 in T2DM nephropathy subjects. In contrast, there was no correlation between TNF- $\alpha$ levels in the diabetes group and serum creatinine in the study of Spranger et al (1995). 
$457-468$

Guzel et al (2012) and Yaseen et al (2012) observed a significantly elevated IL-6 level in diabetic patients. The results of Pitsavos (2007) are consistent with the hypothesis that low-grade inflammation is closely involved in the pathogenesis of T2DM. It has been demonstrated in various studies that circulating IL-6 levels are elevated in T2DM (Muller et al, 2002; Tönjes et al, 2010). According to the study of Marques-Vidal et al (2012), the subjects who developed T2DM had significantly higher baseline level of IL-6 than subjects who remained free of T2DM.

Various studies have demonstrated that circulating IL-6 levels are elevated in insulin resistant states such as impaired glucose tolerance and T2DM (Tönjes et al, 2010).

In contrast, serum levels of IL-6 were not significantly elevated in the diabetic group compared to the non-diabetic group (Andriankaja et al, 2009). IL-6 was found to be decreased in T2DM patients compared to normal controls (Al-Shukaili et al, 2013).

Gul et al (2013) have found elevations in levels of IL-8, IL-6 and TNF- $\alpha$ in diabetic patients with myocardial infarction as compared with non-diabetic patients with myocardial infarction and control subjects. Mirza et al (2012) found that IL-8, TNF- $\alpha$ and IL-6, when stratified on the basis of $\mathrm{HbA}_{1 \mathrm{c}}$ values, were most significantly elevated in the group with $\mathrm{HbA}_{1 \mathrm{c}}$ values $>6.5 \%$ of Mexican Americans.

The mean serum TNF- $\alpha$ and IL-8 levels increased with the stage of diabetic retinopathy, and the highest levels were found in patients with proliferative diabetic retinopathy (PDR). The PDR patients had significantly higher serum IL- 8 and TNF- $\alpha$ levels compared with non-proliferative (NPDR) patients, no DR (NDR) patients and controls. Serum levels of these parameters for NPDR patients were also significantly higher compared with those of NDR patients and controls. On the other hand, IL-8 and TNF- $\alpha$ levels of patients with NDR were comparable with those of controls (Doganay et al, 2002).

The diabetic patients had significantly higher concentrations of IL- 8 and MCP-1. The IL- 8 and MCP- 1 levels in the aqueous humor increased as the severity of DR increased (Dong et al, 2013).

Diabetes is a heterozygous disorder and atherosclerosis is its risk factor. It has been almost proved that inflammation has an important role in atherosclerosis. Evidences show that chemokines such as IL- 8 and MCP-1 have an important role in this process by attracting monocytes inside the arterial wall (Spranger et al, 2003). Monocytes are the primary inflammatory cells which are found in atherosclerotic plaques (Shin et al, 2002). Apart from their role in inflammation, chemokines are involved also in other biological activities as angiogenesis, hematopoesis, as well as in enhancing the host response to tumors (Buc and Bucova, 2000). IL-8 mediates the binding of glucose-stimulated monocytes to the endothelium and it has been shown that it is involved in plaque formation of atherosclerosis disease. Therefore, the high incidence of heart disease and atherosclerosis in T2DM patients may be due to IL-8 (Simonini et al, 2000).

Circulating MCP-1 has been found significantly increased in patients with T2DM (Piemonti et al, 2009). The plasma level of MCP-1 has been generally found increased in obese children (Breslin et al, 2012). Wakabayashi et al (2011) have found that
IL-8 and MCP-1 concentrations in samples from diabetic patients were significantly higher than the concentrations for nondiabetic controls, and the aqueous humor levels of IL-8 and MCP-1 were closely correlated with the severity of DR (Petrovic et al, 2007; Praidou et al, 2009; Liu et al, 2010; Cheung et al, 2012).

We found a positive correlation between AGEs and MCP-1 in PGC group. Some other studies showed an association between AGEs and induction of expression of MCP-1 (Yamagishi et al, 2002; $\mathrm{Gu}$ et al, 2006). Enhanced generation of AGEs stimulated the secretion of MCP-1 either alone, or synergistically combined with high concentrations of glucose (Banba et al, 2000; Schacky et al, 2001).

\section{Conclusions}

The obtained results showed that in order to recognize the risk of diabetic complications it may be useful to monitor the parameters of fluorescent advanced glycation and low-grade inflammation especially in patients with poor glycemic control. The fluorimetric assay is advantageous because this method is simple, time saving and not expensive.

Despite good glycemic compensation in patients with T2DM, the levels of AGEs and inflammatory markers remained significantly elevated in comparison with healthy controls.

We found significantly decreased levels of $\mathrm{HbA}_{1 \mathrm{c}}$ and AGEs in patients who used statins compared to patients who used fibrates. We observed a beneficial impact of treatment with OAD agents + insulin on levels of IL- 8 , TNF- $\alpha$ and TAG in comparison with treatment with insulin alone.

\section{References}

1. Abou-Seif MA, Youssef AA. Evaluation of some biochemical changes in diabetic patients. Clin Chim Acta 2004; 346: 161-170.

2. Agarwal, N, Chitrika A, Bhattacharjee J, Jain SK. Correlation of tumor necrosis factor- $\alpha$ and interleukin- 6 with anthropometric indices of obesity and parameters of insulin resistance in healthy north Indian population. JIACM 2011; 12 (3): 196-204.

3. Ahmad R, Al-Mass A, Atizado V, Al-Hubail A, Al-Ghimlas F, AlArouj M, Bennakhi A, Dermine S, Behbehani K. Elevated expression on the toll like receptors 2 and 4 in obese individuals: Its significance for obesity-induced inflammation. J Inflamm (Lond) 2012; 9 (1): e48.

4. Al-Shukaili A, Al-Ghafri S, Al-Marhoobi S, Al-Abri, S, Al-Lawati, J, Al-Maskari, M. Analysis of inflammatory mediators in type 2 diabetes patients. Int J Endocrinol 2013; 2013: e976810.

5. Andriankaja OM, Barros SP, Moss K, Panagakos FS, DeVizio W, Beck J, Offenbacher S. Levels of serum interleukin (IL)-6 and gingival cervicular fluid of IL-1 beta and prostaglandin E (2) among non-smoking subjects with gingivitis and type 2 diabetes. J Periodontol 2009; 80 (2): 307-316.

6. Aronson D. Hyperglycemia and pathobiology of diabetic complications. Adv Cardiol 2008; 45: 1-16.

7. Aso Y, Inukai T, Tayama K, Takemura Y. Serum concentrations of advanced glycation endproducts are associated with the development of atherosclerosis as well as diabetic microangiopathy in patients with type 2 diabetes. Acta Diabetol 2000; 37: 87-92. 
8. Banba N, Nakamura T, Matsumura M, Kuroda H, Hattori Y, Kasai K. Possible relationship of monocyte chemoattractant protein-1 with diabetic nephropathy. Kidney Int 2000; 58: 684-690.

9. Bansal S, Chawla D, Siddarth M, Banerjee BD, Madhu SV, Tripathi AK. A study on serum advanced glycation end products and its association with oxidative stress and paraoxonase activity in type 2 diabetic patients with vascular complications. Clin Biochem 2013; 46: 109-114.

10. Barbarroja N, Lopez-Pedrera C, Garrido-Sanchez L, Mayas MD, Oliva-Olivera W, Bernal-Lopez MR, EI Bekay R, Tinahones FJ. Progression from high insulin resistance to type 2 diabetes does not entail additional visceral adipose tissue inflammation. PLoS ONE 2012; 7 (10): e48155.

11. Basta G, Schmidt AM, De Caterina R. Advanced glycation end products and vascular inflammation: implications for accelerated atherosclerosis in diabetes. Cardiovasc Res 2003; 63 (4): 582-592.

12. Bastard JP, Maachi M, Lagathu C, Kim MJ, Caron M, Vidal H, Capeau J, Feve B. Recent advances in the relationship between obesity, inflammation, and insulin resistance. Eur Cytokine Netw 2006; 17: 4-12.

13. Beaglehole R, Yach D. Globalisation and the prevention and control of non-communicable disease: The neglected chronic disease of adults. Lancet 2003; 362 (9387): 903-908.

14. Boulanger E, Grossin N, Wautier MP, Taamma R, Wautier JL. Mesothelial Rage activation by AGEs enhances VEGF release and potentiates capillary tube formation. Kidney Int 2007; 71: 126-133.

15. Boulanger E, Wautier MP, Wautier JL, Boval B, Panis Y, Wernert N, Danze PM, Dequiedt P. AGEs bind to mesothelial cells via RAGE and stimulate VCAM-1 expression. Kidney Int 2002; 61: 148-156.

16. Breslin WL, Johnston CA, Strohacker K, Carpenter KC, Davidson TR, Moreno JP, Foreyt JP, McFarlin BK. Obese Mexican American children have elevated MCP-1, TNF-alpha, monocyte concentration, and dyslipidemia. Pediatrics 2012; 96: E2034-2038.

17. Buc M, Bucova M. Chemokines. Bratisl Lek Listy 2000; 101 (9): 507-511.

18. Bush M, Franke S, Stein G, Wolf G, Collaborative Study Group. Is the serum concentration of pentosidine a predictor of cardiovascular events in patients with type 2 diabetes and kidney disease? Dtsch Med Wschr 2007; 132: 1810-1814.

19. Calder PC, Ahluwalia N, Brouns F, Buetler T, Clement K, Cunningham K, Esposito K, Jönsson LS, Kolb H, Lansink M, Marcos A, Margioris A, Matusheski N, Nordmann H, O'Brien J, Pugliese G, Rizkalla S, Schalkwijk C, Tuomilehto J, Wärnberg J, Watzl B, Winklhofer-Roob BM. Dietary factors and low-grade inflammation in relation to overweight and obesity. Brit J Nutr 2011; 106 (S3): S1-S78.

20. Cinti S, Mitchel, G, Barbatelli G, Murano I, Ceresi E, Faloia E, Wang S, Fortier M, Greenberg AS, Obin MS. Adipocyte death defines macrophage localization and function in adipose tissue of obese mice and humans. J Lipid Res 2005; 16 (11): 2347-2355.

21. Czyzewska J, Wasilewska K, Kaminska J, Koper O, Kemona H, Jakubowska, I. Assess the impact of concentrations of inflammatory markers IL-6, CRP in the presence of albuminuria in patients with type 2 diabetes. Pol Merkur Lek 2012; 32 (188): 98-102.

22. DCCT - The Diabetes Control and Complications Trial Research Group. The effect of intensive treatment of diabetes on the development and progression of long-term complications in insulin-dependent diabetes mellitus. N Engl J Med 1993; 329: 977-986.
23. De la Maza MP, Garrido F, Escalante N, Leiva L, Barrera G, Schnitzel S, Zanolli M, Verdaguer J, Hirsch S, Jara N, Bunout D. Fluorescent advanced glycation end-products (ages) detected by spectro-photofluorimetry, as a screening tool to detect diabetic microvascular complications. J Diab Mellitus 2012; 2 (2): 221-226.

24. Doganay S, Everekliuglu C, Er H, Turköz Y, Sevinc A, Mehmet N, Savli H. Comparison of serum NO, TNF-alpha, IL-1beta, sIL-2R, IL-6 and IL-8 levels with grades of retinopathy in patients with diabetes mellitus. Eye (Lond) 2002; 16 (2): 163-170.

25. Dolhofer-Bliesener R, Lechner B, Deppisch R, Ritz E, Gerbitz KD. Immunologicsl determination of advanced glycosylation end-products in human blood and urine. Nephrol Dial Transplant 1995; 10 (5): 657-664.

26. Donath MY, Shoelson SE. Type 2 diabetes as an inflammatory disease. Nat Rev Immunol 2011; 11: 98-107.

27. Dong N, Xu B, Wang B, Chu L. Study of 27 aqueous humor cytokines in patients with type 2 diabetes with or without retinopathy. Mol Vis 2013 ; 19: 1734-1746.

28. Erbagci AB, Tarakcioglu M, Coskun Y, Sivasli E, Sibel Namiduru E. Mediators of inflammation in children with type I diabetes mellitus: cytokines in type I diabetic children. Clin Biochem 2001; 34: 645-650.

29. Festa A, D’Agostino R Jr, Howard G, Mykkanen L, Tracy RP, Haffner SM. Chronic subclinical inflammation as part of the insulin resistance syndrome: the Insulin Resistance Atherosclerosis Study (IRAS). Circulation 2000; 102: 42-47.

30. Festa A, D'Agostino R Jr, Tracy RP, Haffner SM. The Insulin Resistance Atherosclerosis Study: Elevated levels of acute-phase proteins and plasminogen activator inhibitor-predict the development of type 2 diabetes: the Insulin Resistance Atherosclerosis Study. Diabetes 2002; 51: 1131-1137.

31. Ford ES. Body mass index, diabetes, and C-reactive protein among U.S. adults. Diabetes Care 1999; 22: 1971-1977.

32. Freeman DJ, Norrie J, Caslake MJ, Gaw A, Ford I, Lowe GD, O'Reilly DS, Packard CJ, Sattar N. The West of Scotland Coronary Prevention Study: C-reactive protein is an independent predictor of risk for the development of diabetes in the West of Scotland Coronary Prevention Study. Diabetes 2002; 51: 1596-1600.

33. Brenner H, Koenig W. Association between C-reactive protein and features of the metabolic syndrome: a population-based study. Diabetes Care 2000; 23: 1835-1839.

34. Goh S-Y, Cooper ME. The role of advanced glycation end products in progression and complications of diabetes. J Clin Endocrinol Metab 2008; 93 (4): 1143-1152.

35. Gottsäter A, Szelag B, Kangro M, Wroblewski M, Sundkvist G. Plasma adiponectin and serum advanced glycated end-products increase and plasma lipid concentrations decrease with increasing duration of type 2 diabetes. Eur J Endocrin 2004; 151: 361-366.

36. Goyal R, Faizy AF, Siddiqui SS, Singhai M. Evaluation of TNF- $\alpha$ and IL-6 levels in obese and non-obese diabetics: pre- and post-insulin effects. North Amer J Med Sci 2012; 4 (4): 180-184.

37. Gu L, Hagiwara S, Fan Q, Tanimoto M, Kobata M, Yamashita M, Nishitani T, Gohda T, Ni Z, Qian J, Horikoshi S, Tomino Y. Role of receptor for advanced glycation end-products and signaling events in advanced glycation end-product-induced monocyte chemoattractant protein-1 expression in differentiated mouse podocytes. Nephrol Dial Transplant 2006, 21:299-313. 
38. Gul A, Rahman MA, Salim A, Simjee SU. Advanced glycation end products in senile diabetic and nondiabetic patients with cataract. J Diab Compl 2009; 23 (5): 343-348.

39. Guzel, S, Seven A, Kocaoglu A, Ilk B, Guzel EC, Saracoglu V, Celebi A. Osteoprotegerin, leptin and IL-6: Association with silent myocardial ischemia in type diabetes mellitus. Diab Vasc Dis Res 2012; 10 (1): 25-31.

40. Hajer GR, van Haeften TW, Visseren FLJ. Adipose tissue dysfunction in obesity, diabetes and vascular disease. Eur Heart J 2008; 29: 2959-2971.

41. Hatfield J. Advanced glycation end-products (AGEs) in hyperglycemic patients. J Young Invest 2005; 19: 1-3.

42. Hegab Y, Gibbons S, Neyses L, Mamas A. Role of advanced glycation end products in cardiovascular disease. World J Cardiol 2012; 4 (4): 90-102.

43. Henle T, Deppisch R, Beck W, Hergesell O, Hänsch GM, Ritz E. Advanced glycated end-products (AGE) during haemodialysis treatment: discrepant results with different methodologies reflecting the heterogeneity of AGE compounds. Nephrol Dial Transplant 1999; 14: 1968-1975.

44. Chen Y-H, Wu G, Wang J-B, Huang G-X Chen X-M. Determination and clinical significance of serum IL- 6 and TNF- $\alpha$ in patients with type 2 diabetes mellitus. Chinese J Clin Rehab 20037 (18): 2536-2537.

45. Cheung CM, Vania M, Ang M, Chee SP, Li J. Comparison of aqueous humor cytokine and chemokine levels in diabetic patients with and without retinopathy. Mol Vis 2012; 18: 830-837.

46. Chilelli NC, Burlina S, Lapolla A. AGEs, rather than hyperglycemia, are responsible for microvascular complications in diabetes: A "glycoxidation-centric" point of view. Nutr Metab Cardiovasc Dis 2013; 23 (10): 913-919.

47. Inagaki Y, Yamagishi S, Okamoto T, Takeuchi M, Amano S. Pigment epithelium-derived factor prevents advanced glycation end productsinduced monocyte chemoattractant protein-1 production in microvascular endothelial cells by supressing intracellular reactive oxygen species generation. Diabetologia 2003; 46 (2): 284-287.

48. Kafle D, Singh N, Singh SK, Mandal F, Rimal B. Correlation between hyperglycemia, inflammation and oxidative stress in type-2 diabetic nephropathy subjects. Int J Pharm Biol Arch 2012; 3 (6): 1508-1511.

49. Kalousová M, Škrha J, Zima T. Advanced glycation end-products and advanced oxidation protein products in patients with diabetes mellitus. Phys Res 2002; 51: 597-604.

50. Kalousová M, Zima T, Tesař V, Stípek S. New markers of advanced damage caused by oxidative and carbonyl stress. Sbor Lek 2001; 102: 465-472.

51. Kalousová M, Zima T, Tesař V, Sulková S, Fialová L. Relationship between advanced glycoxidation end products, inflammatory markers/ acute-phase reactants, and some autoantibodies in chronic hemodialysis patients. Kidney Int 2003; 6, Suppl. 84: S62-S64.

52. Kerkeni M, Saidi A, Bouzidi H, Letaief A, Ben Yahia S Hammami M. Pentosidine as a biomarker for microvascular complications in type 2 diabetic patients. Diab. Vasc Dis Res 2012; 10: 239-245.

53. King GL. The role of inflammatory cytokines in diabetes and its complications. J Periodontol 2008; 79 (8): 1527-1534.

54. Korpáš J, Jakuš J. The expiration reflex fromthe vocal foôd. Acta Physiol Hung 2000; 87 (3): 201-215.

55. Laimer M, Ebenbichler CF, Kaser S, Sandhofer A, Weiss H, Nehoda H, Aigner F, Patsch JR. Markers of chronic inflammation and obesity: a prospective study on the reversibility of this association in middle-aged women undergoing weight loss by surgical intervention. Int J Obes Relat Metab Disord 2002; 26: 659-662.

56. Liu J, Shi B, He S, Yao X, Willcox MD, Zhao Z. Changes to tear cytokines of type 2 diabetic patients with or without retinopathy. Mol Vis 2010; 16: 2931-2938.

57. Makita Z, Radoff S, Rayfield EJ, Yang Z, Skolnik E, Delaney V, Friedman EA, Cerami A, Vlassara H. Advanced glycosylation end products in patients with diabetic nephropathy. N Engl J Med 1991; 325 (12): 836-842.

58. Marques-Vidal P, Bastardot F, von Känel R, Paccaud F, Preisig M, Waeber G Vollenweider P. Association between circulating cytokine levels, diabetes and insulin resistance in a population-based sample (CoLaus study). Clin Endocrinol 2013; 78 (2): 232-241.

59. Marques-Vidal P, Schmid R, Bochud M, Bastardot F, von Känel R, Paccaud F, Glaus J, Preisig M, Waeber G, Vollenweider P. Adipocytokines, hepatic and inflammatory biomarkers and incidence of type 2 diabetes. The CoLaus study. PLoS ONE 2012; 7 (12): e51768.

60. Miller AD, Nonaka S, Jakuš J, Yates BJ. Modulation of vomiting by the medullary midline. Brain Researxch 1996; 737 (1-2): 51-58.

61. Mirza S, Hossain M, Mathews Ch, Martinez P, Pino P, Gay J.L, Rentfro A, McCormick JB, Fisher-Hoch SP. Type 2-diabetes is associated with elevated levels of TNF-alpha, IL-6 and adiponectin and low lewels of leptin in a population of Mexican Americans: a cross sectional study. Cytokine 2012; 57: 136-142.

62. Muller S, Martin S, Koenig W, Hanifi-Moghaddam P, Rathmann W, Haastert B, Giani G, Illig T, Thorand B, Kolb H. Impaired glucose tolerance is associated with increased serum concentrations of interleukin 6 and co-regulated acute-phase proteins but not TNF-alpha or its receptors. Diabetologia 2002; 45: 805-812.

63. Münch G, Keis R, Wessels A, Riederer P, Bahner U, Heidland A, Niwa T, Lemke HD, Schinzel R. Determination of advanced glycation end products in serum by fluorescence spectroscopy and competitive ELISA. Eur J Clin Chem Clin Biochem 1997; 35: 669-677.

64. Nass N, Simm A. Advanced glycation end products (AGEs) in diabetes. AHMN Endokrin 2009; 4: 63-75.

65. Navarro JF, Mora C. Role of inflammation in diabetic complications. Nephrol Dial Transplant 2005; 20: 2601-2604.

66. Negre-Salvayre A, Salvayre R, Auge N, Pamplona R, Portero-Otin M. Hyperglycemia and glycation in diabetic complications. Antiox Redox Signal 2009; 11: 3071-3109.

67. Nieto-Vasquez I, Vernández-Veledo S, Krámer DK, Vila-Bedmar R, Garcia-Guerra L, Lorenzo M. Insulin resistance associated to obesity: the link TNF-alpha. Arch Physiol Biochem 2008; 114 (3): 183-194.

68. Nilsson J, Jovinge S, Niemann A, Reneland R, Lithell H. Relation between plasma tumor necrosis factor- $\alpha$ and insulin sensitivity in elderly men with non-insulin-dependent diabetes melitus. Atheroscler Thromb Vasc Biol 1998; 18: 1199-1202.

69. Ono Y, Aoki S, Ohnishi K, Yasuda T, Kawano K, Tsukada Y. Increased serum levels of advanced glycation end-products and diabetic complications. Diabetes Res Clin Pract 1998; 41: 131-137.

70. Pasceri V, Willerson JT, Yeh ETH. Direct proinflammatory effect of C-reactive protein on human endothelial cells. Circulation 2000; 102 (18): 2165-2168. 
71. Petrovic MG, Korosec P, Kosnik M, Hawlina M. Vitreous levels of interleukin-8 patients with proliferative diabetic retinopathy. Am J Ophthalmol 2007; 143 (1): 175-176.

72. Piarulli F, Sartore G, Ceriello A, Ragazzi E, Reitano R, Nollino L, Cosma C, Fedele D, Lapolla A. Relationship between glyco-oxidation, antioxidant status and microalbuminuria in type 2 diabetic patients. Diabetologia 2009; 52: 1419-1425.

73. Pickup JC, Crook MA. Is type II diabetes mellitus a disease of the innate immune system? Diabetologia 1998; 41 (10): 1241-1248.

74. Piemonti L, Calori G, Lattuada G, Mercalli A, Ragogna F, Garancini MP, Ruotolo G, Luzi L, Perseghin G. Association between plasma monocytes chemoattractant protein-1 concentration and cardiovascular disease mortality in middle-aged diabetic and nondiabetic individuals. Diabetes Care 2009; 32: 2105-2110.

75. Pitsavos Ch, Tampourlou M, Panagiotakos DB, Skoumas Y, Chrysohoou Ch, Nomikos T, Stefanadis Ch. Association between low-grade systemic inflammation and type 2 diabetes mellitus among men and women from ATTICA study. Rev Diabet Stud 2007; 4: 98-104.

76. Popko K, Gorska E, Stelmaszczyk-Emmel A, Plywaczewski R, Stoklosa A, Gorecka D, Pyrzak B, Demkow U. Proinflammatory cytokines IL- 6 and TNF- $\alpha$ and the development of inflammation in obese subjects. Eur J Med Res 2010; 15: 120-122.

77. Pradhan AD, Manson JE, Rifai N, Buring JE, Ridker PM. C-reactive protein, interleukin 6 , and risk of developing type 2 diabetes mellitus. JAMA 2001; 286: 327-334.

78. Praidou A, Klangas I, Papakonstantinou E, Androudi S, Georgiadis N, Karakiulakis G, Dimitrakos S. Vitreous and serum levels of plateletderived growth factor and their correlation in patients with proliferative diabetic retinopathy. Curr Eye Res 2009; 34 (2): 152-161.

79. Rapoport MJ, Mor A, Vardi P, Ramot Y, Winker R, Hindi A, Bistritzer T. Decreased secretion of Th2 cytokines precedes up-regulated and delayed secretion of Th1 cytokines in activated peripheral blood mononuclear cells from patients with insulin-dependent diabetes mellitus. J Autoimmun 1998; 11: 635-642.

80. Rasouli N, Kern PA. Adipocytokines and the metabolic complications of obesity. J Clin Endocrinol Metab 2008; 93: S64-S73.

81. Rácz O, Vícha T, Pačin J. Glycohemoglobin, glycation of proteins and diabetes mellitus. Martin: Osveta, 1989.

82. Rekeneire N, Peila R, Ding J, Colbert LH, Visser M, Shorr RI, Kritchevsky SB, Kuller LH, Strotmeyer ES, Schwartz AV, Vellas B, Harris TB. Diabetes, hyperglycemia, and inflammation in older individuals: the health, aging and body composition study. Diabetes Care 2006; 29 (8): 1902-1908.

83. Sampathkumar R, Balasubramanyam M, Rema M, Premanand C, Mohan V. A novel advanced glycation index and its association with diabetes and microangiopathy. Metabolism 2005; 54 (8): 1002-1007.

84. Sebekova K, Somoza V. Dietary advanced glycation endproducts (AGEs) and their health effects - PRO. Mol Nutr Food Res 2007; 51 (9): 1079-1084.

85. Sharp PS, Rainbow S, Mukherjee S. Serum levels of low molecular weight advanced glycation end products in diabetic subjects. Diabet Med 2003; 20 (7): 575-579.

86. Shimoike T, Inoguchi T, Umeda F, Nawata H, Kawano K, Ochi H. The meaning of serum levels of advanced glycosylation and products in diabetic nephropathy. Metabolism 2000; 49 (8): 1030-1035.
87. Shin WS, Szuba A, Rockson SG. The role of chemokines in human cardiovascular pathology: Enhanced biological insights. Atherosclerosis 2002; 160 (1): 91-102.

88. Shoelson SE, Lee J, Goldfine AB. Inflammation and insulin resistance. J Clin Invest 2006; 116: 1793-1780.

89. Schmidt AM, Yan SD, Yan SF, Stern DM. The multiligand receptor RAGE as a progression factor amplifying immune and inflammatory presponses. J Clin Invest 2001; 108: 949-955.

90. Simonini A, Moscucci M, Muller DW, Bates ER, Pagani FD, Burdick MD, Strieter RM. IL-8 is an angiogenic factor in human coronary atherectomy tissue. Circulation 2000; 101 (13): 1519-1526.

91. Spranger J, Kroke A, Möhlig M, Hoffmann K, Bergmann MM, Ristow M, Boeing H, Pfeiffer AF. Inflammatory cytokines and the risk to develop type 2 diabetes: Results of the prospective population-based European Prospective Investigation into Cancer and Nutrition (EPIC)Potsdam Study. Diabetes 2003; 52 (3): 812-817.

92. Spranger J, Meyer-Schwickerath R, Klein M, Schatz H, Pfeiffer A. TNF-alpha level in the vitreous body. Increase in neovascular eye diseases and proliferative diabetic retinopathy (in German). Med Klin (Munich) 1995; 90 (3): 134-137.

93. Temelkova-Kurktschiev T, Siegert G, Bergmann S, Henkel E, Koehler C, Jaross W, Hanefeld M. Subclinical inflammation is strongly related to insulin resistance but not to impaired insulin secretion in a high risk population for diabetes. Metabolism 2002; 51: 743-749.

94. Tchorzewski H, Glowacka E, Banasik M, Lewkowicz P, SzalapskaZawodniak M. Activated T lymphocytes from patients with high risk of type I diabetes mellitus have different ability to produce interferon-gamma, interleukin- 6 and interleukin-10 and undergo anti-CD95 induced apoptosis after insulin stimulation. Immunol Lett 2001; 75: 225-234.

95. Tönjes A, Fasshauer M, Kratzsch J, Stumvoll M, Blüher M. Adipokine pattern in subjects with impaired fasting glucose and impaired glucose tolerance in comparison to normal glucose tolerance and diabetes. PLoS ONE 2010; 5 (11): e13911.

96. Tsigos C, Kyrou L, Chala E, Tsapogas P, Stavridis JC, Raptis SA, Katsilambros N. Circulating tumour necrosis factor alpha concentrations are higher in abdominal versus peripheral obesity. Metabolism 1999; 48 (10): 1332-1335.

97. van den Oever IAM, Raterman HG, Nurmohamed MT, Simsek S. Endothelial dysfunction, inflammation, and apoptosis in diabetes mellitus. Mediators Inflamm 2010; 2010: e792393.

98. Venugopal SK, Devaraj S, Yuhanna I, Shaul P, Jialal I. Demonstration that $\mathrm{C}$-reactive protein decreases eNOS expression and bioactivity in human aortic endothelial cells. Circulation 2002; 106 (12): 1439-1441.

99. von Schacky C, Baumann K, Angerer P. The effect of n-3 fatty acids on coronary atherosclerosis: results from SCIMO, an angiographic study, background and implications. Lipids 2001; 36: S99-S102.

100. Wagner Z, Wittmann I, Mazák I, Schnitzel R, Heidland A KientschEngel K, Nagy J. N (epsilon)- (carboxymethyl)lysine levels in patients with type 2 diabetes role of renal function. Am J Kidney Dis 2001;38 (4): 785-791.

101. Wakabayashi Y, Usui Y, Okunuki Y, Kezuka T, Takeuchi M, Iwasaki T, Ohno A, Goto H. Increases of vitreous monocyte chemotactic protein 1 and interleukin 8 levels in patients with concurrent hypertension and diabetic retinopathy. Retina 2011; 31 (9): 1951-1957.

102. Wautier JL, Schmidt AM. Protein glycation: a firm link to endothelial cell dysfunction. Circ Res 2004; 95: 233-238. 
457-468

103. Wautier MP, Chappey O, Corda S, Stern DM, Schmidt AM, Wautier JL. Activation of NADPH oxidase by AGE links oxidant stress to altered gene expression via RAGE. Am J Physiol Edocrinol Metab 2001; 280: 685-694.

104. Weisberg SP McCann D, Desai M ,Rosenbaum M, Leibel L, Ferrante A. Obesity is associated with macrophage accumulation in adipose tissue. J Clin Invest 2003; 112 (12): 1796-1808.

105. Williams MD, Nadler JL. Inflammatory mechanisms of diabetic complications. Curr Diab Rep 2007; 7 (3): 242-248.

106. Yamagishi S, Inagaki Y, Okamoto T, Amano S, Koga K, Takeuchi M, Makita Z. Advanced glycation end product-induced apoptosis and overexpression of vascular endothelial growth factor and monocyte chemoattractant protein-1 in human-cultured mesangial cells. J Biol Chem 2002; 277: 20309-20315.

107. Yamamoto Y, Yamamoto H. RAGE-mediated inflammation, type 2 diabetes, and diabetic vascular complication. Front Endocrinol 2013; 4: e105.

108. Yaseen F, Jaleel A, Aftab J, Zuberi A, Alam E. Circulating levels of resistin, IL-6 and lipid profile in elderly patients with ischemic heart disease with and without diabetes. Biomarkers Med 2012; 6 (1): 97-102.
109. Yudkin JS. Inflammation, obesity, and metabolic syndrome. Horm Metab Res 2007; 39 (10): 707-709.

110. Yudkin JS, Stehouwer CD, Emeis JJ, Coppack SW. C-reactive protein in healthy subjects: associations with obesity, insulin resistance, and endothelial dysfunction: a potential role for cytokines originating from adipose tissue? Arterioscler Thromb Vasc Biol 1999; 19: 972-978.

111. Zahorska-Markiewicz B, Janowska J, Olzanecka-Glinianowicz M, Zurakowski A. Serum concentration of TNF-alpha and soluble TNF-alpha receptors in obesity. Int J Obes Relat Metab Disord 2000; 24 : 1392-1395.

112. Zietz B, Schäffler A, Büttner R, Schölmerich J, Palitzsch KD. Elevated levels of leptin and insulin but not of TNF alpha are associated with hypertension in type 2 diabetic males. Exp Clin Endocrinol Diabetes 2000; 108 (4): 259-264.

113. Zilin S, Naifeng $\mathbf{L}$, Bicheng $\mathbf{L}$, Jiping $\mathbf{W}$. The determination of AGE-peptides by flow injection assay, a practical marker of diabetic nephropathy. Clin Chim Acta 2001; 313: 69-75.

Received February 21, 2014. Accepted April 18, 2014. 